\title{
A tensão dialética entre o eu e o outro em Eu hei-de amar uma pedra, de António Lobo Antunes
}

\author{
Tatiana Prevedello*
}

Ce n'est pas du tout ma faute. C'est faux de dire: Je pense: on devrait dire: On me pense. Pardon du jeu de mots.

Je est un autre. Tant pis pour le bois qui se trouve violon, et nargue aux inconscients, qui ergotent sur ce qu'ils ignorent tout à fait!

Arthur Rimbaud

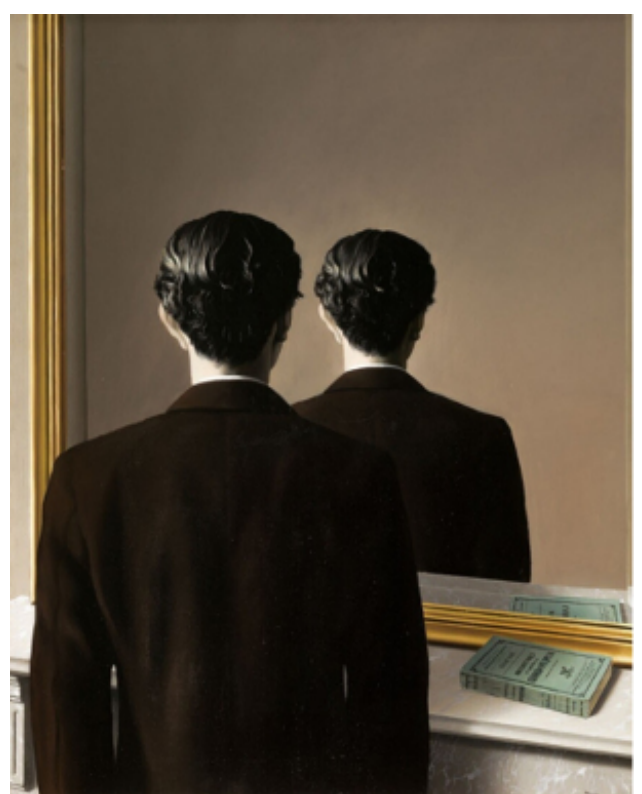

La reproduction interdite, de René Magritte

"Doutora em letras pela Universidade Federal do Rio Grande do Sul (UFGRS), Porto Alegre, RS, Brasil. E-mail: t_prevedello@hotmail.com 


\section{"Sobejos que nos miram na insistência do remorso": o "eu" contra o "outro"}

A declaração de Rimbaud - "Je est un autre" - e a tela de Magritte, La reproduction interdite, selecionadas para compor as epígrafes desse texto, oferecem subsídios para mediar nossa reflexão sobre o estatuto das identidades narrativas delineadas no romance Eu hei-de amar uma pedra, de António Lobo Antunes. O "eu" e o "outro", a personagem e o reflexo dos indivíduos ficcionais projetados no texto, encarnam a multiplicidade, a imprecisão, o fragmento, pois os sujeitos jamais se fixam, seja pela sua autoanálise ou elaboração da consciência de outrem, em algum ponto estável. Enquanto o "outro" da enunciação rimbaudiana não se mostra apenas na pluralidade do "eu", mas rompe sua qualidade circular e homogênea, o trabalho operacionalizado pelo "ser alheio" que habita o interior do indivíduo possibilita que sua identidade se multiplique no papel de personagem no contexto ficcional. A alteridade negada, ou reinventada, torna-se, simultaneamente, sujeito e objeto de uma conformação textual construída no equívoco, na descontinuidade, na renovação, e ambos - o "eu" e o "outro" - são produzidos como personagens indeterminadas, instáveis, imprevisíveis.

O reflexo que altera a projeção no espelho do retrato de Edward James, de Magritte, mostra uma duplicação que nada inverte, ao produzir uma repetição que inaltera qualquer propriedade do sujeito refletido na superfície do espelho. A "reprodução proibida" é criada pelo espelho da tela ao capturar o reflexo da insólita imagem do homem que se autocontempla, enquanto o livro, posicionado sobre o aparador, mostra-se espelhado. O indivíduo tem a sua identidade negada pelo seu próprio olhar ou pela função alterada do objeto que deveria contemplar a sua face? O que o ser que contempla a imagem vê, porém, não é um homem, mas uma imagem pintada por um artista que, ao elaborar os enigmas da representação, modifica as propriedades convencionais a respeito da semelhança e da ilusão da cópia. $\mathrm{Na}$ tela, o homem, espectador de si mesmo, olha para imagem que o observador externo também vê. A óbvia constatação que pode ser depreendida é que um sujeito jamais pode olhar para si próprio senão numa representação que "espelhe" sua identidade.

A reflexão a respeito da narrativa de Lobo Antunes constrói-se à medida que suas técnicas de fazer ficção elaboram um exímio questionamento sobre os conflitos identitários do sujeito, em um projeto artístico que indaga incisivamente o trabalho de escritura do texto. A produção ficcional de Lobo Antunes demonstra distanciar-se do conceito clássico de narração. A tendência apresentada pelo autor, de subverter os gêneros literários convencionais, pode refletir uma contingência histórico-cultural e ideológica presente na sociedade portuguesa do século XX, causadora de um profundo mal-estar social, filtrada e redimensionada pela voz narrativa. Desde sua estreia na ficção, em 1979, o autor reconfigura em sua atividade literária a aflição de um universo aparentemente destituído de sentido, em 
que as fronteiras físicas e mentais são revestidas por um caráter desumanizado. No decorrer de mais de três décadas de trabalho dedicado à literatura, Lobo Antunes elegeu a modalidade narrativa como sua forma de expressão artística. A escrita romanesca situa o aspecto da unidade dos textos em um plano proeminente e, mesmo que o conjunto ficcional antuniano, constituído por 28 romances e cinco livros de crônicas, publicados até 2017, mostre uma nítida evolução no decorrer dos anos, o romance é a modalidade que melhor se compromete com sua expressão escrita.

Ao explorar a questão do "eu" e da "identidade narrativa", no texto $O$ si-mesmo como um outro, o filósofo francês Paul Ricoeur (1991) admite que essa se apresenta na dialética da "mesmidade" e "ipseidade". A identidade do "eu", visto como entendimento e razão, transforma-se em algo impessoal e abstrato. O "cogito" cartesiano se desvincula do mundo espaço-temporal e adquire o aspecto de uma certeza apenas formal. Conforme Ricoeur (1991), é Nietzsche que melhor explora a dúvida cartesiana, ao examinar as propriedades do "cogito", pois a dúvida se equipara à certeza de pensar, e tanto a ação de duvidar quanto o indivíduo que duvida são enquadrados como ficções, tal como podemos ver na pretensa declaração: "(ou sou eu que imagino ou o António Lobo Antunes julgando que devo imaginar a fim de que o romance melhore)" (ANTUNES, 2004, p. 143). O filósofo mostra que, em inúmeras vezes, a "identidade-idem" é reduzida à "mesmidade". Esta dimensão identitária equivale ao núcleo imutável, estático e contínuo de permanência no tempo. Para o autor, o caráter é um exemplo paradigmático desta característica da identidade. A "mesmidade" possui referência ao núcleo sedimentado da identidade do sujeito, o qual pode ser tanto identificado como reidentificado e manter-se estável no passado, presente e futuro. A identidade na condição de "mesmidade" abrange vários sentidos. O primeiro deles é a unicidade, equivalente a uma identidade numérica, na qual o nome pode designar mais que uma ocorrência, sem que as mesmas venham a se distinguir. O oposto dessa identidade é a pluralidade. Uma segunda perspectiva compreende a identidade como semelhança extrema, na qual certas ocorrências são de tal maneira parecidas que podem ser substituídas umas em re-

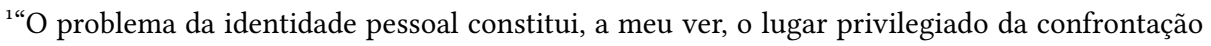
entre os dois usos maiores do conceito de identidade, que muitas vezes evoquei sem nunca tematizálos verdadeiramente. Evoco os termos da confrontação: de um lado, a identidade como mesmidade (latim: idem; inglês: sameness; alemão: Gleichheit), do outro, a identidade como ipseidade (latim: ipse; inglês: selfhood; alemão: Selbstheit). A ipseidade, tenho afirmado muitas vezes, não é a mesmidade. [...] À primeira vista, com efeito, a questão da permanência no tempo liga-se exclusivamente à identidade-idem [...]. A mesmidade é um conceito de relação e uma relação de relações. [...] a ipseidade do si implica uma forma de permanência no tempo que não seja redutível à determinação de um substrato [...]. Ao falar de nós mesmos, dispomos de fato de dois modelos de permanência no tempo, que resumo por dois termos ao mesmo tempo descritivos e emblemáticos: o caráter e a palavra considerada. [...] Minha hipótese é que a polaridade desses dois modelos de permanência da pessoa resulta de que a permanência do caráter exprime a ação de recobrir quase completamente uma pela outra da problemática do idem e da do ipse, enquanto que a fidelidade a si na manutenção da palavra dada marca o afastamento extremo entre a permanência do si e do mesmo e, portanto, atesta plenamente a irredutibilidade das duas problemáticas uma à outra” (Ricoeur, 1991, p. 140-143).
} 
lação às outras, o que faz com que essa identidade tenha a diferença como contrário. $\mathrm{O}$ terceiro sentido remete à identidade como permanência no tempo. Todavia, Ricoeur concebe outro modo de relacionar a identidade com o tempo, através da "identidade-ipse" ou "ipseidade", que é a forma dinâmica de conservação do "eu" no decorrer do tempo, refletindo o "si-mesmo" que se conserva na diversidade de suas expressões e atos. O termo "eu" demonstra seguir o processo da "ipseidade", pois não reflete uma identidade estática ou imutável, mas refere o sujeito que, em cada circunstância discursiva, é ele próprio sem ser o mesmo. Conforme Ricoeur (1991), o "si-mesmo" que cada indivíduo é, diferente de todos os outros, localiza-se no polo da "identidade-ipse", ou "ipseidade". A investigação sobre este polo da identidade requer que a pergunta "quem sou eu?" não seja substituída pela pergunta "o que sou eu?”. Ao buscar uma resposta à indagação “quem sou eu?”, enuncia-se, no primeiro plano, um conjunto de predicados físicos, equivalentes a caracterização do corpo do indivíduo; de qualidades psíquicas, correspondentes ao seu caráter e personalidade; e de valores, princípios e credos que definem a conduta de cada um e que se identificam com o que há de permanente no sujeito. A narrativa é constituída como um espaço privilegiado para a "hermenêutica do si", pois, sob uma perspectiva, executa a exigência do distanciamento, ao se tornar autônoma em relação ao contexto sociopsicológico da sua produção e dá unidade à história de uma vida, propiciando a avaliação ética de uma existência em sua conformação teleológica.

Além de demonstrar a percepção sobre o aspecto destrutivo do tempo, que faz sucumbir à fúria e à fome de Chronos espaços, indivíduos e objetos, a narrativa de Eu hei-de amar uma pedra, quando não nega, questiona a validade de qualquer estatuto temporal estável e engendra à ideia de Borges (2012, p. 25) do tríplice presente - "el presente es indefinido, [...] el futuro no tiene realidad sino como esperanza presente, $[. .$.$] el passado no tiene realidad sino como recuerdo presente"$ -, eleita, aqui, como um de nossos eixos norteadores para a compreensão da temporalidade. Em um texto que encena em surdina o espetáculo da deterioração, da ruína, do desaparecimento e da morte, a memória é acionada como mecanismo de retenção dos fatos e personagens. Consideramos que as águas instáveis da fonte da deusa da memória, todavia, não permitem nenhum mergulho seguro a quem deseje se aventurar como escafandrista e melhor explorar seu manancial, pois os destroços de todos os naufrágios existenciais que jazem em suas profundezas, diante da forma imprecisa como os narradores configuram o texto, não possibilitam grandes chances de restaurar com exatidão os fios condutores dessa narrativa.

Seguindo o argumento que guia a hipótese principal de nosso estudo, é da articulação entre tempo e memória que emerge a representação dos indivíduos, sobretudo os "seres ausentes" abrigados nas páginas de Eu hei-de amar uma pedra. O processo de construção da narrativa desencadeia uma série de reflexões sobre a forma como uma personagem narra a si mesma. No caso de um texto em que as perspectivas e pontos de vista narrativos são muitos, onde um mesmo sujeito é pensado por diversas vozes ambíguas e contraditórias entre si e o próprio estatuto da autoria também é colocado em descrédito - "(se pudesse terminava o li- 
vro imediatamente, se me dessem liberdade, se dependesse de mim terminava, detesto o que conto)" (ANTunEs, 2004, p. 598) -, torna-se uma missão difícil reunir os estilhaços de uma alteridade e montar, a partir de um espelho fragmentado, uma unidade coerente, que possa oferecer um reflexo articulado sobre a personalidade de uma personagem. Analisemos, pois, as deformidades que a desunião de espelhos partidos cria, ao configurar a representação dos seres ausentes, em que o "eu", muitas vezes de forma involuntária, é situado contra o "outro".

Na narrativa Eu hei-de amar uma pedra, é bastante explorada a abertura do "outro" no processo de criação e desenvolvimento das personagens. O emprego deste recurso possibilita que a ficção melhor elabore a constituição das individualidades criadas. As indicações referenciais do romance são mínimas e entre as poucas personagens que recebem nome próprio figuram o senhor Querubim, o primo Casimiro, a Raquel ou Raquelinha. O processo de elaboração dos sujeitos ficcionais, que, como em todos os romances de Lobo Antunes, não se ancora nos cânones clássicos, constrói identificações que remetem à "funções" específicas desempenhadas em cada estágio do texto, passíveis de evolução à medida que as páginas avançam, ou alterações significativas, dependendo do olhar que as enquadra.

"Pimpolho", a personagem masculina mais expressiva da trama, também é designada, de acordo com o contexto em que se situa, ou com o narrador que assume a condução do enredo, como o "senhor das quarta-feiras na hospedaria da Graça", o "senhor que herdei de minha mãe", entre outros; "trambolhos" é o adjetivo proferido pelo pai de "pimpolho", no tratamento para com o filho e a esposa, abandonados para sempre ao decidir partir para Paris em um comboio de imigrantes. A mulher, que durante 52 anos mantém um caso extraconjugal com "pimpolho", é referida como a "bailarina de corda" ou a "vizinha do toldo", mas após a morte se transforma na "doente de 82 anos", ou "senhora com o saquito do crochet". Em "As consultas", que são cinco, essa "doente de 82 anos, sexo $\%$, idade aparente coincidindo com a real", acompanhada de um "saquito de crochet", se apresenta ao psiquiatra, "com dificuldade de verbalizar o motivo da consulta" (ANTUNES, 2004, p. 251). O contexto narrativo, em seguida, possibilita a constatação de que a personagem não nomeada, agora envelhecida, é a antiga amante do pimpolho, aquela que outrora fora a "bailarina que girava, girava" (ANTunEs, 2004, p. 310). A razão das consultas, permeada de sintomas como "queixas de depressão sem irritabilidade nem sequelas psicomotoras” (ANTUNES, 2004, p. 272) são atribuídas:

ao falecimento de uma pessoa chegada ocorrido há três meses, em companhia da paciente, num hotel

numa pensão

numa hospedaria de Lisboa cujo nome e localização não refere, relacionando o dito falecimento com o início dos sintomas não apenas pela morte em si mas pelo facto de não haver podido participar, como era seu desejo e por razões que não aduz, no velório e no enterro, limitando-se 
a assistir às cerimônias fúnebres distanciada da família como se visitasse outra campa qualquer (ANTUNES, 2004, p. 272).

Também é recorrente no texto a invocação a personagens como "minha mãe", "a madrinha da minha mãe" "minha filha mais nova" "minha filha mais velha", "meu genro", "a criatura de chapéu de palha com cerejas de feltro". Em "As visitas", a voz da filha da madrinha da mãe do "pimpolho" é que abre a primeira parte da seção, constituída por três visitas, nas quais ainda as menções textuais ao "pimpolho" estabelecem conexões narrativas com os episódios anteriormente apresentados, nas vozes passadas que se presentificam de forma ecoica. Os indicadores da passagem do tempo, aqui, igualmente sugerem a destruição cronológica e a imprecisão espaço-temporal:

[...] o pimpolho de início acompanhando a mãe e nas últimas visitas sozinho, crescido, impaciente, a máquina de costura a ensurdecer o andar com a agulha

(tic, tic, tic)

imitando os relógios, o pimpolho à entrada do cubículo, nos intervalos da agulha

-Tem até ao fim do mês para sair de cá (ANTunEs, 2004, p. 273).

[...] o seu pai às quarta-feiras a hesitar, a esconder-se

(durante cinquenta e dois anos a hesitar, a esconder-se)

e mal você distraída a entrar, a mulher que ele conheceu antes de conhecer a sua mãe, julgou ter morrido no sanatório em Coimbra (ANTUNES, 2004, p. 392).

A quarta e última parte do romance, constituída por sete capítulos, possui narradores específicos. As histórias se interligam à criatura "de chapéu de palha com cerejas de feltro" (ANTunEs, 2004, p. 446); à "senhora com o saquito de crochet" (ANTUNES, 2004, p. 467); ao senhor, agora morto, "de propósito numa dessas espeluncas baratas [...] acompanhado pela vizinha do toldo" (ANTUNEs, 2004, p. 487); e às indagações angustiadas da filha mais velha do "pimpolho". As sessões de "As narrativas" concedem voz à esposa oficial de "pimpolho", ingênua quanto à traição: "O meu marido faleceu há dois meses junto aos colegas do emprego numa dessas quartas-feiras em que saía contra minha vontade e a vontade do doutor para um café" (ANTUNES, 2004, p. 511). Ocorre o retorno do espectro da "criatura do chapéu de palha, [...] a fotografia dela na camilha do Jardim Constantino mas qual, a velhota de bengala, a rapariga das tranças, uma prima secundária em que ninguém reparava" (ANTUNEs, 2004, p. 545), e a apresentação de lamúrias: ouvese o lamento da filha mais velha, "a gente a supor que as coisas terminam e aí 
estão elas vivas, os meus pais vivos mesmo que duas pedras com datas e letras" (ANTunes, 2004, p. 571). A "última narrativa”, o fecho do livro, é articulada pela voz da mulher que mescla suas vivências atuais: "completam-se três anos para o mês que vem, no dia onze, que ele morreu" (Antunes, 2004, p. 593), às experiências passadas: "quando eu doente em Coimbra dava atenção aos pinheiros" (ANTUNES, 2004, p. 594). Nesse cenário em que as personagens também são identificadas pelos lugares onde se encontram, o contexto espacial está orientado entre alguns pontos de Lisboa, identificados pelo leitor, como a "Photo Royal do Beato", o "segundo andar do Jardim Constantino", a "hospedaria da Graça". São mencionados, ainda, outros locais, como Sintra e Tavira, que são de uma significativa importância para o entendimento da trama textual.

A personagem "pimpolho" é, na primeira parte do texto, o grande escafandrista memorialístico, o arqueólogo que resgata as alteridades perdidas, pois seu "mergulho" nas águas da fonte de Mnemosyne, equipado apenas com uma coleção fotográfica, extrai os estilhaços de um "eu" múltiplo, contraditório e em permanente processo de construção-destruição, (des)alinhado em relação a todos os "outros" indivíduos dessa ficção.

As questões que focalizam a problemática relacionada ao caráter ficcional configuram-se como princípios articuladores de intensas reflexões, que têm posto em discussão as tradicionais formas de identidade, como a do sujeito cartesiano, concebido como "pensante e consciente, situado no centro do conhecimento" (HALL, 2002, p. 27). Esse motivo cria uma arena propícia para o surgimento não de uma identidade centrada, unificada e coerente, mas de identidades fragmentárias, instáveis e em permanente (des)construção, tal como professam as palavras da artista literária e intelectual portuguesa, Ana Hatherly, em O mestre:

Tudo está sempre a destruir tudo. Ou qualquer coisa. Ou alguém. Mas estamos sempre a destruir tudo ou qualquer coisa. Ou alguém. Os construtores demolem. No lugar onde estava o sopro, pormos pedras ou palavras: sinónimo de construção. Ou destruição. Ou acção" (HATHerly, 1995, p. 21).

Ou, como ainda observa Cabral:

A dinâmica do polissistema literário assenta na noção de canonização e não-canonização das obras literárias geradas a partir de uma troca permanente entre os sistemas literários e os sistemas culturais. Nada é fixo, tudo se move - este é um lema de todos os campos da actividade humana. A contemporaneidade molda, no entanto, o lema intemporal de contornos novos num vaivém entre identidade e alteridade em que predomina uma dilatação do presente, em que a simultaneidade triunfa sobre uma lógica da consequência e da sequencialidade e em que as transformações são apenas acumulações numa mesma temporalidade dilatada quanto vazia (CABRAL, 2011, p. 137). 
A citação se coaduna com nossa opção de investigar três paradigmas de natureza instável - tempo, identidade e memória - e, simultaneamente, passíveis às mais ambíguas tentativas de reconstrução narrativa: em nossa primeira leitura, vimos que os seres e as coisas sucumbem ao tempo e sobrevivem apenas na memória. É pelas vias dessa faculdade psíquica, portanto, que os sujeitos são refigurados no texto. No processo que aciona os recursos provenientes da hermenêutica do tempo e da memória são elaboradas, por sua vez, variadas formas de ficcionalização da alteridade, constituintes da "identidade narrativa", a qual é definida por Ricoeur (1991, p. 168) da seguinte forma: "a natureza verdadeira da identidade narrativa só se revela, na minha opinião, na dialética da ipseidade na mesmidade. Nesse sentido, esta última representa a maior contribuição da teoria narrativa à construção do si". E quando o "eu" questiona sua identidade e sua natureza discursiva? Observemos um fragmento da seção final do livro, a "Última narrativa" de Eu hei-de amar uma pedra:

Se calhar Tavira já não existe. Nem Sintra. Há quanto tempo isto foi? Terei inventado tudo? Sonhado tudo? Demoro na resposta mas penso que não: completam-se três anos para o mês que vem, no dia onze, que ele morreu. Nunca mais fui à Graça: para quê? E no entanto creio não ter inventado porque me lembro da hospedaria, da janela diante da qual nos sentávamos, à espera. Achava eu que à espera embora me perguntasse de quem dado não recebermos visitas, nenhuma voz no corredor (ANTUNES, 2004, p. 593).

Cada personagem ficcionalizada em Eu hei-de amar uma pedra atém-se, de forma reiterada, em dizer - e desdizer - a "si-mesma" e a os "outros" com os quais, em algum momento, interagiu. A alteridade de todos os sujeitos narrativos e, inclusive, o próprio estatuto da autoria, são deslegitimados, incessantemente questionados ou colocados em descrédito. A voz do fragmento supracitado é, nessa última seção do romance, atribuída à já otagenária ex-amante do falecido "pimpolho", outrora designada como a "bailarina de corda", a qual constituiu com ele, nos episódios finais da relação, um "casal de idade" (AntunEs, 2004, p. 593).

A identidade das personagens de Eu hei-de amar uma pedra se ampara no conceito de "continuidade ininterrupta entre o primeiro e o último estádio do desenvolvimento do que nós consideramos indivíduo" (Ricoeur, 1991, p. 141-142). O respectivo critério que, conforme Ricoeur, subsiste em todas as situações em que o crescimento e o envelhecimento se manifestam como motivos de dessemelhança e variações numéricas - aqui entra o aspecto da identidade como reidentificação do mesmo, admitindo que conhecer é reconhecer "a mesma coisa duas vezes, $\mathrm{n}$ vezes" (RICOEUR, 1991, p. 141) -, por demonstrações que se expressam em uma série ordenada de mudanças, que, como defende Ricoeur, investigadas uma a uma, colocam sob ameaça a semelhança, sem todavia destruí-la. Esse procedimento é realizado pelo "pimpolho", na primeira parte do romance, ao analisar os retratos seus e de 
outras personagens em idades sucessivas da vida, o que mostra que o tempo se configura como um fator de "dessemelhança, de afastamento, de diferença" (RIcoeur, 1991, p. 142). A questão do caráter é um elemento de importante conformação na narrativa de Eu hei-de amar uma pedra, uma vez que um mesmo sujeito é visto e interpretado por si mesmo e por outros indivíduos ficcionais, entre os quais ocorreu alguma forma de interação. Esse aspecto é assim descrito por Ricoeur:

O caráter me parece hoje ainda como o outro polo de uma polaridade existencial fundamental. Mas, em vez de conceber o caráter dentro de uma problemática da perspectiva e da abertura, como o polo acabado da existência, interpreto-o aqui em função do seu lugar na problemática da identidade. Esse deslocamento de entonação tem como virtude principal pôr novamente em questão o estatuto da imutabilidade do caráter tido como adquirido [...]. De fato, essa imutabilidade revela-se de um gênero bem particular, como o atesta a reinterpretação do caráter em termos de disposição adquirida. Com essa noção permite-se, enfim, tematizar ela própria a dimensão temporal do caráter. O caráter, eu diria hoje, designa o conjunto de disposições duráveis com que reconhecemos uma pessoa. É por essa razão que o caráter pode constituir o ponto limite em que a problemática do ipse torna-se indiscernível da do idem e leva a não distinguir entre uma e outra. Convém, por conseguinte, interrogar-se sobre a dimensão temporal da disposição: é ela que enviará para mais longe o caráter no caminho do narrável da identidade pessoal (RICOEUR, 1991, p. 146).

O estilhaçar do "eu" - de todos os "eus" elaborados pela narrativa - não ocorre de forma abrupta ou acidental, mas se inscreve no tempo e subsiste na memória dos sujeitos cujas consciências são atuantes no texto. É, sobretudo, a memória a principal articuladora desse processo, pois o exercício de sua faculdade permite a sobrevivência dos seres, e suas respectivas identidades, no tempo. Em um tempo impreciso, múltiplo, articulado na tríplice expressão do presente - "presente das coisas passadas", "presente das coisas presentes" e "presente das coisas futuras" subsiste a memória, palácio composto de escadas traiçoeiras e alçapões que conduzem aos porões do esquecimento. É nas operações mnemônicas que impera toda a natureza de lapsos e contradições, que possibilitam o "eu" pensar sobre "simesmo como um outro", alternando "ipseidade" e "mesmidade", ou as dimensões da "identidade-ipse" e da "identidade-idem". A identidade e a memória formam uma equação que possibilita ao indivíduo construir comparações de algo em relação a "si-mesmo" no decorrer do tempo. E, nesse ponto, expressa-se uma oposição entre identidade e diversidade, pois a memória permite a avaliação de elementos que caracterizaram e identificaram o sujeito em momentos específicos de sua existência. Observemos um fragmento de Eu hei-de amar uma pedra, no qual diferentes personagens são evocadas pelo "pimpolho" ao articular tempo e memória na interpretação do "eu" e dos "outros": 
o que supus o comboio de França e era uma corveta no rio ou a garrafa de volta ao aparador ou os suspiros da muralha se uma onda mais forte, eu a subir para a cama afastando cabelos

- Mãe

eu o responsável, o tutor, eu o dono, o que cresceu tanto este ano, o que haveria de crescer ano após ano até poisar a mão na mão da minha mulher na fotografia do álbum,eu continuando a crescer no segundo andar do Jardim Constantino [...]

(não sei onde)

$[\ldots]$

- Pimpolho

(nunca soube do primo Casimiro nem da minha vida no Beato)

$[\ldots]$

- Pai

a minha filha mais velha

- Pai

julgando-me demasiado idoso, com as ilusões, os caprichos, as patetices dos idosos, a fitar a minha mulher, a perguntar-lhe em segredo

- Tem ido ao médico ele?

a perguntar, com o bico do lábio, à irmã

- Já reparaste no pai?

e elas a conversarem entre si que eu bem as entendia apesar de mudas, a minha filha mais velha tem setenta anos o pobre, setenta e um quase, a minha filha mais nova, de mão diante da cara, faz setenta e um em julho e portanto o raciocínio, a memória, as artérias, tudo aquilo que derivado ao tempo se estraga (ANTUNEs, 2004, p. 98-100).

O fragmento visa ilustrar um processo narrativo recorrente em todo o texto, o qual envolve sobreposições espaço-temporais, acionamento da memória e as refrações identitárias. $\mathrm{O}$ aspecto que, para nós, torna a citação supracitada significativa reside no ponto de que a mesma reproduz, a partir da percepção da mais destacável personagem masculina da trama, o "pimpolho", diversas formas como, no decorrer do tempo, um mesmo sujeito pensa sobre "si-mesmo" e os principais "outros" com quem partilha as suas experiências existenciais: o pai, o primo Casimiro, a mãe, a mulher, as filhas. O elemento relevante para a nossa análise reside no fato de um mesmo episódio narrativo reunir as percepções do "eu" que se inscreveram no decorrer do tempo, relativas a um indivíduo que, ao ser refigurado pelo leitor, pode se ver, ao mesmo tempo, como "bebé", criança, homem adulto em diversas fases de sua existência e "velho". Ao recompor o itinerário de sua vida, 
extrai de suas experiências as percepções equivocadas que foram sendo construídas, e que apenas o suceder dos anos - "setenta anos, faz setenta e um em julho" - possibilitou que fossem moldadas. Todavia, essa afirmação também é passível de questionamento, porque se a maturidade permite que o individuo reflita sobre a totalidade de sua existência e dela retire juízos valorativos que as idealizações da infância e da juventude impediram que se firmassem, o declínio das faculdades físicas e mentais - "o raciocínio, a memória, as artérias, tudo aquilo que derivado ao tempo se estraga" - impossibilita, novamente, que se vislumbrem pontos de vista confiáveis. Os equívocos e autotraições subsistem a qualquer tentativa de interpretação do "eu" e dos "outros" em um texto onde tudo se (in)sustém na mobilidade da escrita.

Conforme Ricoeur (1991), a mais elevada contribuição da identidade narrativa no processo de construção do "eu" é a mediação operada na dialética entre "mesmidade" e "ipseidade". A personagem que fala sobre "si" ("pimpolho") e os demais sujeitos ficcionais, a maioria deles inominados ou apenas designados por um substantivo comum, ainda que com caráter próprio, operam intercâmbios nessa dialética identitária. Ao evocarem o "eu" e os "outros", as questões identitárias se inscrevem no decorrer da história de sua vida e das existências que seguem paralelas a sua trajetória ficcional, por meio das quais são estabelecidas conexões que relacionam os eventos inscritos no tempo e na memória e transformam a história em uma unidade de sentidos.

A identidade narrativa se nivela à identidade das personagens, a qual se elabora de forma articulada com a unidade temporal da história narrada. Por sua vez, a unidade temporal do texto resulta de uma síntese do heterogêneo, como afirma Ricoeur, de uma "concordância discordante" por meio da qual os diversos acontecimentos e peripécias são integrados no encadeamento da intriga: o pai, que abandona a família e parte para Paris, de onde jamais retorna; a mãe do "pimpolho" que, mesmo sem esquecer o marido, envolve-se com o primo Casimiro, o qual, por sua vez, também imigra para a América e segue um roteiro que, apenas de forma velada, é expresso pelo narrador; a separação entre o "pimpolho" e a "bailarina de corda", o casamento, o reencontro com a antiga namorada e o envolvimento, na condição de amantes, até que a relação seja novamente interrompida, desta vez pela morte do "pimpolho" em uma hospedaria da Graça. Observamos, assim, que os eventos do texto, ainda que aparentemente surjam de forma descontínua na consciência dos hipotéticos múltiplos narradores, integram o movimento configurador da narrativa e são destituídos de sua neutralidade impessoal. Apesar das sobreposições temporais e memorialísticas, da repetição compulsiva de determinados eventos e da aparente desconexão entre as partes que integram o livro, a forma como a intriga do romance é encadeada envolve os episódios, que parecem ser aleatórios e circunstanciais, pela técnica que modula a retrospectiva e a antevisão dos fatos, essenciais para a fundamentação da unidade da intriga e a construção (transformação, modificação) da identidade das personagens. 
Cada um dos narradores de Eu hei-de amar uma pedra tem o poder de selecionar, contradizer, suprimir e assumir suas falhas memorialísticas a respeito daquilo que está a narrar. Os sujeitos narrativos delimitam, assim, o princípio e o fim - ou a repetição e permutação ostensiva - dos conjuntos de ações. Esse mecanismo constrói uma unidade de sentido que engloba todos esses processos por meio de um ato refigurador. $\mathrm{O}$ texto permite que sejam testadas múltiplas formas de ação, de modo que cada uma delas subordina determinadas consequências e implicações éticas. As personagens ficcionais, munidas de suas valorações identitárias, não podem ser interpretadas como uma entidade que se distingue de suas vivências textuais ou se expresse como mera portadora de acontecimentos. A identidade de cada personagem, como afirma Ricoeur (1991), apresenta vínculos de solidariedade à história narrada, de modo que é em nome da coerência da história que são construídas as identidades das personagens.

Acompanhamos, até agora, como o "pimpolho" configura a si mesmo e as outras personagens com as quais interage em seu percurso narrativo. Seguindo a proposta apresentada pelo romance, veremos como esse processo se inverte, ou seja, como as outras personagens veem o "pimpolho" e, ao tecerem os mais variados juízos de valor sobre esse homem, contemplam-se a si mesmas. A identidade narrativa, como constata Ricoeur (1991) é, portanto, uma síntese do heterogêneo capaz de conciliar diversidades. A identidade das personagens não se expressa por uma permanência do mesmo no decorrer da história, mas se transforma em um processo dinâmico, que segue o desencadear de toda a intriga e obriga o "eu" a refletir sobre si no turbilhão de suas desmemórias e contradições.

\section{“Ouviram falar de nós? Saberiam quem éramos?”: o resgate do “eu” pelo "outro"}

A dialética da personagem, tratada por Ricoeur (1991) como "concordânciadiscordante", inscreve-se no intervalo entre os dois polos da permanência no tempo: "mesmidade" e "ipseidade". A identidade narrativa envolve uma dimensão ética, baseada nas decisões que as personagens assumem diante dos eventos com os quais se deparam. O que nos propomos, neste momento, com o objetivo de confrontar algumas formas como o "eu" concebe o "outro", e suas respectivas inversões, é analisar as expressões das personagens que possuem voz própria na narrativa Eu hei-de amar uma pedra e podem pensar a si mesmas e aos outros indivíduos com os quais contracenam. Devemos considerar que algumas personagens relevantes no texto apenas "são pensadas" e, mesmo quando suas vozes aparecem, é um "outro" que as articula por meio de suas lembranças. Portanto, a inscrição de indivíduos como o senhor Querubim, o pai e a mãe do "pimpolho", o primo Casimiro, depende da intercessão desse "outro" no corpo textual. Podemos afirmar que suas vozes são "terceirizadas" pela mediação, sobretudo do "pimpolho" que, à proporção que narra a si mesmo, ocupa-se em tecer aos outros: 
o senhor Querubim a aconselhar-me ao ouvido

- Mostra que não tens medo sorri

e portanto eu, pimpolho, a sorrir no retrato, eu um cordeiro de matadouro, eu um boi de pescoço erguido, cabeça para acolá, ambas as mãos na cintura (ANTUNES, 2004, p. 57)

[...] o meu pai sem se despedir, numa vozita maçada

- Trambolhos (Antunes, 2004, p. 38)

e ainda bem que a máquina de costura impediu o senhor Querubim de dar fé do que você disse primo Casimiro, ainda bem que anulou a chuva em Alcântara, quem por acaso compreendeu

- Um dia volto pimpolho (ANTUnEs, 2004, p. 52)

[...] o senhor Querubim ciente que a zebra permanecia na loja

- Qual zebra pimpolho?

a minha mãe tentou ajudar-me e o empregado crucificou-a no espaldar com as mãos amarelas

- Não me estrague a pose madame (ANTUnes, 2004, p. 26).

Nenhuma das vozes das personagens destacadas nos fragmentos - o senhor Querubim, o "pai", o primo Casimiro, a "mãe" - assume, de forma imperativa, a narração dos episódios da trama, pois elas apenas se expressam, de modo refratário e fragmentado, na consciência do sujeito que, por meio de um dispositivo visual fotográfico os reconstitui em suas memórias, pertencentes ao passado, em relação à atitude de contemplar as fotos, mas são presentes do ponto de vista da apresentação do discurso textual. As personagens que já estão mortas no momento em que são configuradas pelo discurso do "pimpolho", as quais não possuem voz própria e só se manifestam por via da recordação de um "outro", não têm a capacidade de dizer qualquer coisa sobre si mesmas, uma vez que, valendose da apropriação pluralizada do trocadilho rimbaudiano, "são pensadas". E a personagem que as reconfigura no discurso de seu pensamento memorialístico, por sua vez, é "pensada" por outros com os quais suas lembranças interagem no plano do texto. As vozes narrativas são tecidas a partir de vários pontos de vista, muitos deles passíveis de serem confrontados. Observemos, assim, a forma como a filha da dona da hospedaria da Graça narra suas percepções sobre o casal de amantes:

[...] eu na hospedaria da Graça que herdei da minha mãe, uma casa decente para pessoas decentes onde se exige educação e respeito, cada quarto meia hora no máximo excepto a senhora e o senhor das quartafeiras que desde eu criança toda a tarde no 12, o senhor que parecia trazer consigo as gaivotas 


\section{$[\ldots]$}

a senhora com o saquito de crochet, provavelmente sempre o mesmo, que chegava antes dele

(nunca depois, antes) (ANTUnEs, 2004, p. 467).

As circunstâncias que uniram, afastaram e reaproximaram o "pimpolho" da mulher que, nos episódios referentes à sua juventude, é designada como a "bailarina de corda" e, depois, quando refigurada textualmente por outro narrador, em sua velhice, passa a ser a "doente de 82 anos, sexo $\$$, idade aparente coincidindo com a real", que também é configurada por outras consciências, sobretudo a do psiquiatra que a analisa. A ela é atribuída a tarefa de narrar a si mesma e, por extensão, dizer o "outro". Quando se apresenta ao médico, após o falecimento do amante na hospedaria da Graça, "vestida de luto, enfeitada por um medalhão de esmalte com o retrato de um homem [...]", declara a razão a qual o psiquiatra atribui o seu estado depressivo: “- Não podia ir ao velório nem ao funeral percebe?" (ANTUNEs, 2004, p. 258).

Informações já referidas são reiteradas pela própria personagem ao médico psiquiatra: "-Encontrei-o aos dezassete senhor doutor" (ANTUNES, 2004, p. 277); "Há cinquenta e três senhor doutor" (ANTUNEs, 2004, p. 290); “- Era virgem senhor doutor" (ANTUNES, 2004, p. 290). Estes elementos do discurso da personagem que destacamos, balizados pela questão temporal, contêm características importantes tanto da "identidade-idem" como da "identidade-ipse", pois ilustram aspectos identitários que se mantiveram no transcorrer do tempo, relativos ao caráter do sujeito e às modificações comportamentais e físicas que nele foram se imprimindo no decorrer do anos:

[...] pode ser que os informassem do casal de idade às quarta-feiras no primeiro andar, educados tranquilos, partindo antes da noite, discretos, se calhar um bocadinho ridículos, pelo lado das árvores, primeiro ele, depois ela, tomando atenção aos degraus, de parede sempre ao alcance dos dedos, imobilizando-se a descansar numa esquina fazendo de conta que se interessavam por uma montra, um gato, o eléctrico iluminado, quase vazio, a descer para Baixa. Alguém ocupa o nosso quarto agora, nosso quarto é como quem diz, o quarto que alugávamos, observando por nós a trepadeira no caixilho: continuará ali, movendo-se devagarinho a assinalar o vento? Julgo que sim: certas coisas, nunca as que supomos mais interessantes, nunca aquelas que nos comoveram, permanecem intactas: a bailarina a girar numa mesa de pé-de-galo por exemplo (ANTUNEs, 2004, p. 593-594).

Os juízos valorativos elaborados tanto pelo "pimpolho" (ou "senhor das quartafeiras") quanto pela "bailarina de corda" (ou "doente de 82 anos", "senhora com o saquito de crochet") sobre a forma como cada um vislumbra o "outro" revestemse de uma atmosfera de profundo afeto, idealização sobre um casamento desejado, 
mas desviado do curso existencial de ambos, e uma união reajustada pelas vias do adultério. O sentimento de "luto e melancolia" (Freud, 2010) é o que prevalece no discurso da senhora que, a partir da parte do romance nomeada como "As consultas", não se desfaz de seu "saquito de crochet", de modo que se torna necessária a intervenção psiquiátrica: "A doente continua de luto com o retrato do homem no medalhão refere que os sintomas se mantêm [...] e lá estão eles com a tristeza, a mania da tristeza, a felicidade da tristeza" (AnTunes, 2004, p. 275). Além da forma como a personagem analisada se expressa no romance, inclusive o próprio psiquiatra demonstra sintomas de luto, ao intercalar suas reflexões ao diagnóstico e às falas da paciente.

O luto, na concepção de Freud, apresenta-se como trabalho de perda, regido por um mecanismo que procura elaborar o trauma advindo daquilo que foi perdido. Terminado o trabalho de enlutamento, o "eu"deveria se tornar novamente disponível para novos investimentos objetais. Todavia, esse processo não aparenta ser superado pelas personagens, pois, à parte das transformações que norteiam a "ipseidade" dos sujeitos, o trabalho de luto se conserva. Diferentemente do que ocorre em relação à melancolia, em que a perda pode não ser identificada e o melancólico não a reconhece, esse mecanismo serve também para diferenciar o que ocorre nesta afecção do que acontece em outras, em que o luto termina. Freud afirma que, na situação patológica da melancolia, há um momento da constituição do "eu" em que algo não se efetuou. Nesse espaço o "eu"se configurou sobre ruínas, falhando a identificação primária. Em decorrência disso, em uma situação posterior, o melancólico estabelece uma intensa ligação do objeto diretamente com o "eu". Ocorre, assim, uma identificação com o objeto. No segundo conjunto de capítulos do romance Eu hei-de amar uma pedra, o próprio médico, à medida que analisa sua paciente e constrói um juízo de valor a seu respeito, entrelaça a seu discurso suas próprias memórias e seus conflitos: "depois da morte do meu pai a minha mãe um medalhão idêntico, a mesma fotografia que na mesinha da sala, sempre com flores ao pé, enquanto da minha irmã nem fotografias nem flores, ao enterrarem-lhe o berço nunca houve irmã no passado" (ANTUNEs, 2004, p. 275).

\footnotetext{
${ }^{2}$ O texto de Sigmund Freud, de 1917, "Luto e melancolia", produz uma comparação constante entre a melancolia e o processo de luto, indicando a grande complexidade do primeiro caso. O luto constitui-se num processo necessário à manutenção das ligações de um objeto nos momentos de perda. Nesse ensaio metapsicológico, Freud introduziu um elemento essencial e, até então, inédito nos quase dois mil anos de teoria da melancolia, ao elucidar que esta é causada por uma perda de objeto. Para o estudo de Freud, o respectivo objeto perdido pode ser uma pessoa amada, um ideal, um sonho ou até mesmo a pátria. A diferença entre a melancolia e o luto é marcada, sobretudo, pelo fato de, no primeiro caso, a dependência do homem em relação a esse objeto se mostrar muito profunda, a ponto de tornar-se uma identificação patológica. Destituindo-se do elo de amor que ligava o melancólico ao seu objeto, instala-se um vazio, o que faz com que o sujeito prefira "canibalizar" o objeto, introjetar seus traços numa ânsia de pertencimento, e converter o seu próprio "eu" em objeto. A perda melancólica atinge diretamente o "eu" do doente, pois a identificação com um objeto perdido era seu sustentáculo.
} 
A esposa do "pimpolho" permanece alheia à longa traição do marido e é vista por essa personagem com desprezo, pois o casamento e as suas filhas só se justificaram em decorrência de o mesmo ter se afastado da antiga namorada, que supunha morta. No momento em que assume o papel de narradora, assim interpreta a morte do marido:

- Daqui a meia hora entregam-nos o seu marido

que faleceu há dois meses, junto aos colegas do emprego, numa dessas quartas-feiras em que saía contra a minha vontade e a vontade do doutor a reunir-se com os outros num café qualquer nunca soube bem onde, Campos de Ourique, Avenidas Novas, um bairro desse gênero com prédios em que gostaria de morar em vez do Jardim Constantino tão desmantelado, tão feio, tenho ideia que uma ocasião me falou na Graça a propósito da doença de um deles,um problema na anca obrigando-o a ficar perto de casa visto que meia dúzia de passos e a perna prendia-se, ainda argumentávamos, o doutor e eu, que um problema na anca não era nada comparado com o coração em papas e o açúcar do sangue, o doutor graças a Deus competente preveniu logo

- Lavo daí as minhas mãos não me responsabilizo (ANTUNES, 2004, p. 536).

No discurso da esposa, é visível a inocência a respeito de uma situação conhecida por todas as outras personagens, que, em algum momento, tornam-se narradoras. A interpretação da esposa sobre o modo de agir de seu marido, suas saídas sempre às quartas-feiras, as razões que o motivavam a desejar residir na Graça e, finalmente, as circunstâncias que permearam seu falecimento, são as únicas que divergem, em grande proporção, das versões e sentimentos elaborados pelos demais narradores. Na fala da amante, interseccionada pelas reflexões e memórias do psiquiatra, o sentimento é de luto. A filha do "pimpolho", tal como sua mãe e irmã, jamais fora objeto de grande afeição do pai, pois sempre que se referia tanto à "filha mais nova" quanto à "filha mais velha" era para demonstrar contrariedade, desaprovação e as inconveniências que causavam. Sua voz refere-se às circunstâncias da morte do pai e ao modo como via sua amante, a vizinha do toldo na praia, revelando vergonha e revolta:

Tinha de ser assim não era pai, de fazer os possíveis por me envergonhar até o último dia, humilhar-me, desejar não haver nascido, não ser sua filha, tinha logo de morrer de propósito numa dessas espeluncas baratas que deviam proibir de alugar quartos à hora acompanhado pela vizinha de toldo que a gente não olhava sequer, não cumprimentava, não percebíamos onde arranjava o dinheiro para estar connosco e infelizmente

$[\ldots]$

e eu a rir-me dela

(se calhar tirei-lhe o retrato sem querer, se calhar a vizinha no álbum) 
$[\ldots]$

nos mentia, a desculpa que às quarta-feiras à tarde os colegas do emprego e em vez dos colegas uma hospedaria na Graça, o edifício ou prédio ou o que fosse a cair de podre (ANTUNES, 2004, p. 487-488).

No fragmento transcrito, verificamos que a memória da filha mais velha do "pimpolho" retrocede para infância quando, aos 7 anos, em companhia da família, estivera em Tavira. O episódio do retrato feito na praia pela menina que, mesmo contrariando a vontade do pai, apossou-se de sua câmera fotográfica - "foi a minha filha mais velha que tirou: não queria emprestar-lhe a máquina dado que por princípio não empresto coisas valiosas a crianças que não descansam enquanto não as estragam" (ANTUNES, 2004, p. 199) - é descrito no capítulo "Nona fotografia”. Entre as linhas que são narradas por seu pai sobre essa cena, são tecidos diversos juízos pejorativos a respeito dessa filha - "(o que se espera de uma catraia de sete anos)" (Antunes, 2004, p. 199) e "com sete anos e já pata-choca, sem graça, a escapar-se" (ANTUNEs, 2004, p. 201); a conclusão dessa personagem - "Mesmo depois de trinta anos o meu pai nunca me perdoou aquela história do rolo" (ANTUNES, 2004, p. 200); e o veredicto do pai - "acho que nunca lhe perdoei aquela história do rolo, cada pic a indignar-me e a seguir a cada pic um soluço" (ANTUNes, 2004, p. 200-201). A importância de se confrontar a cena da infância com a avaliação que a filha mais velha adulta faz após a morte do pai se justifica pelo fato de que, acidentalmente, a menina fotografou a amante de seu pai naquela ocasião, a qual se encontrava próxima à família. Por essa razão, o retrato fora de foco foi conservado no álbum, tal como explica o "pimpolho": "e se colei a fotografia no álbum não é por nenhum de nós [...] mas porque tu de perfil, sumindo-te no crochet com uma madeixa no ar dois toldos adiante" (ANTUNEs, 2004, p. 200).

A conjunção entre as duas cenas mostra uma técnica recorrente em todo o texto: a refiguração do tempo pela memória é essencial para a compreensão da "ipseidade" e "mesmidade" do sujeito, apesar dos aspectos instáveis que modulam cada uma dessas instâncias. A filha mais velha, ao narrar-se a "si" também constrói sua versão sobre a personalidade do pai e da amante, sob um viés que diverge radicalmente daquilo que a ingênua esposa traída diz sobre o marido ou das impressões que o pai e a amante, cada um em momentos específicos, tecem sobre si mesmos e a respeito um do outro.

É possível distinguir em todas as personagens aspectos referentes à elaboração da "identidade do si" e a "identidade do outro". O romance é composto por sujeitos que, ao narrarem a si mesmos, ao relatarem suas experiências, angústias e conflitos, acabam por narrar o "outro". Cada personagem de Eu hei-de amar uma pe$d r a$, ao ser configurado e refigurado na trama narrativa, agrega, pelo processo de autoanálise e dos juízos valorativos que recebe dos outros sujeitos com os quais contracena, diversas "identidades" contraditórias, variáveis, instáveis, que envolvem aspectos importantes relativos à permanência no tempo e à memória. 
O tempo, embora possa ser linearizado em âmbito cronológico em Eu hei-de amar uma pedra, mostra que, se os discursos fragmentários forem articulados em uma ordem que, necessariamente, não é a mesma que conforma o livro em sua formatação gráfica, esta ordem tem suas propriedades alteradas pela consciência das personagens, na forma como confrontam o passado e o presente, e pouco se valem das expectativas futuras. O aspecto destrutivo do tempo comprova que é apenas na memória, contraditória e falaciosa, que os indivíduos e os acontecimentos se sustêm. Pelas vias conflituosas da memória, os sujeitos narrativos, que têm a possibilidade de pensarem a si mesmos, constroem sua identidade e a das outras personagens com as quais realizam alguma forma de interação. Estas, comparadas, confrontadas, divergem potencialmente umas das outras.

Esse processo, ao qual Ricoeur (1991) denomina de "concordância-discordante da personagem", está inscrito na dialética da "mesmidade" e da "ipseidade". Fazse necessária essa reinscrição, uma vez que se estabelece um confronto entre a "concordância discordante da personagem" com a exigência de permanência no tempo relacionada ao que se entende por identidade: sob uma perspectiva, está a "mesmidade" de um caráter e, sob outra, a "ipseidade" na manutenção do "si".

O texto Eu hei-de amar uma pedra explora o papel mediador que a identidade narrativa das personagens realiza entre os extremos da "mesmidade" e da "ipseidade", comprovado pelas "variações imaginativas" submetidas pela representação dos processos identitários na narrativa. Conforme Ricoeur, "o benefício dessas experiências de pensamento é tornar manifesta a diferença entre duas significações da permanência no tempo, fazendo variar a relação de uma com a outra" (RICOEUR, 1991, p. 176). No romance há uma interessante problematização que está a envolver o trabalho de aperfeiçoamento da escrita. O narrador, que, em algumas situações, se autorreferencia, como já discutimos, revela a intenção de aprimorar o trabalho de escritura do livro que está a compor. Na última seção de capítulos do romance, nomeada "As narrativas", é que, de fato, a tensão entre a hipotética vontade autoral e a inscrição de personagens que expressam sua autonomia em relação à criação de outrem adquire uma forte contundência. $\mathrm{O}$ ato de narrar, por sua vez, é constantemente questionado, não apenas nas instâncias discursivas que permitem que o autor se torne figurante na ficção e seja expresso pela voz de uma personagem. Ao chegar as páginas finais da última narrativa - o capítulo totaliza sete -, são manifestados elementos que circunscrevem o desejo de concluir a história e a angústia sobre a finalização do livro, em que uma personagem igualmente múltipla e contraditória como todas as outras - "bailarina de corda", "amante de pimpolho", "senhora do saquito de crochet", "doente de 82 ano" - é incumbida de encerrar a narrativa:

(se pudesse terminar o livro imediatamente, se me dessem liberdade, se dependesse de mim terminava, detesto o que conto)

remava num lago, não insistir na descrição dos telões 
(poupava tanta coisa desnecessária a tanta gente se terminasse já)

$[\ldots]$

(como fechar este livro?)

$[\ldots]$

- Tu é que fechas o livro

a que manda na gente ou a quem mandaram que mandasse na gente, um fulano que decidiu não há muito, acho eu

- És tu que fechas o livro

e embora arrependido de eu a fechar o livro continua por teimosia a escrever

$[\ldots]$

(como fechar este livro?)

[...]

- Fecha este livro como quiseres

terminava-o aqui, com pétalas amarelas descendo na sombra (ANTUNES, 2004, p. 598-605).

O empreendimento narrativo, filtrado por nosso olhar a partir do viés do tempo, da identidade e da memória, conserva sua dimensão hermenêutica na dialética balizada pela oposição extrema que há entre os termos construir-destruir: o tempo cria e corrói, a identidade desenvolve suas alteridades e as refuta, a memória ilumina e contradiz. E, por fim, a considerar que a identidade das personagens, relacionada ao tempo e à memória, não é estática, vemos que o próprio caráter, elemento emblemático da "mesmidade", modela-se em uma dimensão temporal e, independentemente das alterações relativas à "ipseidade" pelas quais será interpretado, ele evolui ao longo do texto até chegar a derradeira (in)conclusão da história.

As diversas alteridades de um "eu" ficcional inscrevem-se no texto de maneira a convidar o leitor a refletir sobre o processo de construção da escrita, pois, afinal, a quem é atribuída a autoria do romance? Quem de fato tem o poder de comandar os meandros narrativos pelas vias da criação literária? Pactuando com o acordo tácito que subjaz entre autor e leitor de qualquer enredo ficcional, percebemos que a primeira instância narradora, em determinados momentos, dissolve-se entre as personagens que, à medida que o enredo avança, intercalam a tarefa de contar a história, confrontando e inclusive contradizendo os múltiplos pontos de vista que emergem do plano ficcional. Ao se aproximar, diríamos aqui, não da conclusão da história, que parece seguir seu fluxo ad infinitum, mas do final do livro em sua condição de objeto formatado graficamente, as indagações sobre a forma de terminar a escrita do romance e sobre a qual sujeito é atribuída a tarefa de pontuar o fim 
do enredo, os questionamentos adquirem um tom bastante veemente. Em um primeiro plano, é possível depreender que, se há a ficcionalização de um autor que parece conceder liberdade às personagens que cria de seguirem seu próprio caminho na história de forma aparentemente autônoma, surge a esta altura do enredo a negação dessa liberdade, uma vez que a personagem que diz estar incumbida de encerrar a história parece não ter escolha e precisa, mesmo contrariando sua vontade, continuar a escrever. A instância de um "outro eu" ficcional firma-se, por conseguinte, como subjacente a um plano de escritura que é alterado e encerra a discussão que permeia as personagens nos episódios finais de Eu hei-de amar uma pedra, quando a voz que afirma dirigir o romance assim encerra a sua obra: "a informar que mudei de plano, não preciso de vocês, sou eu que fecho o livro, vão embora acabou-se" (ANTUNES, 2004, p. 616).

As várias e cambiáveis manifestações identitárias de um mesmo indivíduo, expressas por um "eu" e por quem venha a se encarregar da tarefa de narrar seus coadjuvantes no enredo, preservam razoavelmente a questão da "mesmidade", na medida em que se torna possível acompanhar a evolução - ou o desaparecimento - de personagens inscritos no tempo e refigurados na memória de algum narrador. A "ipseidade", porém, ao confrontar as várias formas como um mesmo indivíduo é apresentado e como cada personagem que tem o poder de dizer a si mesmo descreve seu caráter, suas experiências e maneiras de se relacionar com todos os "outros", manifesta instabilidade e contradição.

\section{Referências}

Antunes, António Lobo. Eu hei-de amar uma pedra. Lisboa: Dom Quixote, 2004.

Borges, Jorge Luis. Ficciones. In: Borges Jorge Luis. Cuentos completos. Buenos Aires: Sudamericana, 2012.

CABral, Eunice. A concepção do romance em Dicionário da obra de António Lobo Antunes. In: Cammaert, Felipe (Org.). António Lobo Antunes: a arte do romance. Lisboa: Texto, 2011.

Cammaert, Felipe (Org.). António Lobo Antunes: a arte do romance. Alfragide: Texto, 2011.

Freud, Sigmund. Introdução ao narcisismo: ensaios de metapsicologia e outros textos (1914-1916). Tradução de Paulo César de Souza. São Paulo: Companhia das Letras, 2010 .

Hall, Stuart. A identidade cultural na pós-modernidade. 7. ed. Rio de Janeiro: DP\&A, 2002.

HATHerly, Ana. O mestre. Lisboa: Quimera, 1995. 
MAgRitTe, René. La reproduction interdite. 1937. Óleo sobre tela. 65,5x79 cm. Rotterdam: Museum Boymans van Beuningen.

Ricoeur, Paul. O si-mesmo como um outro. Tradução de Lucy Moreira Cesar. Campinas: Papirus, 1991.

Rimbaud, Arthur. Poésies. Paris: Librairie Générale Française, 1984. p. 200.

Recebido em 6 de março de 2017.

Aprovado em 25 de setembro de 2017.

\section{Resumo/Abstract/Resumen}

A tensão dialética entre o eu e outro em Eu hei-de amar uma pedra, de António Lobo Antunes

\section{Tatiana Prevedello}

A representação da identidade das personagens do romance Eu hei-de amar uma pedra, de António Lobo Antunes, mostra a instabilidade de indivíduos que não se fixam em uma imagem segura a respeito de si próprios e dos outros com os quais interagem na cena ficcional. A problematização apresentada por Paul Ricoeur em O si-mesmo como um outro (Soi-même comme un autre), relativa aos conceitos de mesmidade (mêmetè), que remete aos aspectos identitários mais estáveis do eu e sua relação com a permanência no tempo, e a ipseidade (ipséité), que abrange a condição mutável do ser, de modo que permaneça o "mesmo" sendo o "outro", auxilia a compreender os mecanismos que engendram a elaboração psíquica dos sujeitos projetados no texto. Nosso propósito é examinar as múltiplas e contraditórias formas de representações identitárias das personagens apresentadas no romance, cujos conflitos interiores auxiliam o desenvolvimento de uma contundente reflexão sobre a alteridade do ser diante da criação ficcional.

Palavras-chave: António Lobo Antunes, Paul Ricoeur, identidade, ipseidade, mesmidade.

The Dialectical Tension between Self and Other in Eu hei-de amar uma pedra, by António Lobo Antunes

\section{Tatiana Prevedello}

The representation of the protagonists' characters in the novel Eu hei-de amar uma pedra, by António Lobo Antunes, demonstrates the instability of individuals who do not adhere to a secure image of themselves or of others with whom they interact in the fictional scene. In Oneself as Another (Soi-même Comme un Autre), 
Paul Ricoeur presents a problematization concerning the concepts of sameness (mêmetè) - an identity of constancy and its relation to permanence in time - and selfhood (ipséité) - the changing condition of being whereby "oneself" is also the "other". These concepts help to understand the mechanisms that engender the psychical development of the subjects described in the text. Here, we examine the multiple and contradictory forms of identity representation of the characters as depicted in the novel; their inner conflicts contribute to the development of a potent reflection on the otherness of being, in fictional creation.

Keywords: António Lobo Antunes, Paul Ricoeur, identity, selfhood, sameness.

La tension dialéctica entre el yo y el otro en Eu hei-de amar uma pedra, de António Lobo Antunes

\section{Tatiana Prevedello}

La representación de la identidad de los personajes de la novela Eu hei-de amar uma pedra, de António Lobo Antunes, muestra la inestabilidad de los individuos que no se fije en una imagen segura de sí mismos y otros con los que interactúan en la escena de ficción. La problematización presentada por Paul Ricoeur en Sí mismo como otro (Soi-même comme un autre) relativa a los conceptos de mismidad (mêmetè), que se refiere a los aspectos más estables de identidad del yo y su relación con la permanencia en el tiempo, y la ipseidad (ipséité), que abarca la condición cambiante de ser, de modo que permanezca el "mismo" siendo el "otro", ayuda a comprender los mecanismos que engendran la elaboración psíquica de los sujetos proyectados en el texto. Nuestro propósito es examinar las múltiples y contradictorias formas de representaciones identitarias de los personajes que aparecen en la novela, cuyos conflictos internos ayudan al desarrollo de una contundente reflexión sobre la alteridad del ser ante la creación ficcional.

Palabras clave: António Lobo Antunes, Paul Ricoeur, identidad, ipseidad, mismidad. 